\title{
INTEGRASI TECHNOLOGICAL PEDAGOGICAL CONTENT KNOWLEDGE (TPACK) DALAM PERANGKAT PEMBELAJARAN DARING GURU BAHASA INDONESIA
}

\author{
Vina Adi Tama1 ${ }^{1}$, Dini Restiyanti Pratiwi ${ }^{2}$ \\ ${ }^{1,2}$ Pendidikan Bahasa dan Sastra Indonesia; Jl. A. Yani Tromol Nomor Pos 1 Pabelan, \\ Fakultas Keguruan dan Ilmu Pendidikan \\ Universitas Muhammadiyah Surakarta \\ Surel: ${ }^{1}$ a310170047@ student.ums.ac.id , ${ }^{2}$ dpr122@ums.ac.id
}

\begin{abstract}
Abstrak
Tujuan dari penelitian ini adalah mendeskripsikan integrasi technological pedagogical content knowledge (TPACK) dalam perangkat pembelajaran daring guru bahasa Indonesia. Penelitian ini menggunakan metode deskriptif kualitatif dengan objek penelitian berupa RPP daring mata pelajaran Bahasa Indonesia di SMP Al Qolam Muhammadiyah Gemolong. Selanjutnya, guru mata pelajaran Bahasa Indonesia di SMP Al Qolam Muhammadiyah Gemolong adalah subjek dari penelitian ini. Penelitian ini dilaksanakan dengan teknik dokumentasi dan wawancara dalam mengumpulkan data. Adapun Pengumpulan data dalam penelitian ini dilakukan dengan menggunakan teknik dokumentasi dan wawancara. Teknik analisis data dalam penelitian ini dilakukan dengan cara reduksi data, penyajian data, dan verifikasi. Hasil penelitian ini menunjukkan bahwa integrasi technological pedagogical content knowledge (TPACK) dikelompokkan menjadi 4 bagian yang meliputi (1) integrasi technological knowledge (TK), (2) integrasi pedagogical knowledge (PK), (3) integrasi content knowledge (CK), dan (4) integrasi technological pedagogical content knowledge (TPCK).
\end{abstract}

Kata kunci: TPACK, Perangkat Pembelajaran Daring, dan Guru Bahasa Indonesia

\begin{abstract}
Abstrak
The purpose of this study is to describe the integration of technological pedagogical content knowledge (TPACK) in Indonesian language teachers' online learning tools. This study uses a qualitative descriptive method with the object of research in the form of online lesson plans for Indonesian subjects at SMP Al Qolam Muhammadiyah Gemolong. Furthermore, the Indonesian language teacher at SMP Al Qolam Muhammadiyah Gemolong is the subject of this study. This research was carried out with documentation and interview techniques in collecting data. The data collection in this study was carried out using documentation and interview techniques. Data analysis techniques in this study were carried out by means of data reduction, data presentation, and verification. The results of this study indicate that the integration of technological pedagogical content knowledge (TPACK) is grouped into 4 parts which include (1) integration of technological knowledge (TK), (2) integration of pedagogical knowledge (PK), (3) integration of content knowledge (CK), and (4) integration of technological pedagogical content knowledge (TPCK)
\end{abstract}

Keywords: TPACK, Online Learning Tool, and Indonesian Language Teacher 


\section{A. PENDAHULUAN}

Kemampuan pedagogik guru dalam melaksanakan pembelajaran tentu perlu diikuti dengan kemampuan dalam konten pembelajaran atau disebut dengan PCK. Pedagogical content knowledge (PCK) adalah pengetahuan pedagogik, praktik, perencanaan, dan metode pembelajaran (Abbit dalam Agustina, 2015:3). Content Knowledge (CK) merupakan pengetahuan konsep suatu pembelajaran (Shulman dalam Agustina, 2015:7). Technological Knowledge (TK) yaitu pengetahuan bagaimana menggunakan teknologi digital. Sedangkan Pedagogical Knowledge (PK) berkaitan dengan proses mengajar (Sulman dalam Agustina, 2015:7)

Integrasi PCK selanjutnya dikembangkan menjadi TPACK. Technological pedagogical content knowledge (TPACK) gabungan dari konten, pedagogik, dan teknologi (Ariani, 2015:82). Kerangka pelaksanaan technological pedagogical content knowledge (TPACK), menurut Rosyid (2016:454) merupakan deskripsi dari pengetahuan guru dalam mengajar secara efektif dengan memanfaatkan teknologi. Kemampuan TPACK guru sangat diperlukan dalam menghasilkan RPP relevan dengan kebutuhan kurikulum 2013 yang mengacu pada ketercapaian kompetensi abad 21.

Technological Pendagogical Content Knowledge (TPACK) ini menjadi penting untuk ditelusuri mengingat saat ini aktivitas pembelajaran juga dilakukan secara daring. Pembelajaran daring itu membutuhkan banyak faktor penunjang, agar pembelajaran yang dilaksanakan mencapai tujuan yang telah dirumuskan. Sekolah SMP Al Qolam Muhammadiyah Gemolong melaksanakan pembelajaran daring dan terdapat faktor penunjang seperti siswa diberi paket data untuk melaksanakan pembelajaran dengan menggunakan berbagai aplikasi yang sudah ditetapkan.

Pada masa pandemi saat ini, pembelajaran belum dapat dilakukan secara tatap muka untuk meminimalisasi terjadinya kontak langsung antara peserta didik dengan guru. Di Indonesia Kemendikbud melalui surat edaran yang dikeluarkan pada 18 Maret 2020 memerintahkan bahwa segala aktivitas di dalam dan di luar ruangan di semua sektor sementara waktu ditunda demi mengurai penyebaran virus covid-19 terutama pada bidang pendidikan. Lebih lanjut ditegaskan dalam Surat Edaran (SE) Nomor 4 Tahun 2020 pada tanggal 24 Maret 2020 bahwa proses belajar selama masa darurat penyebaran virus covid19 dilaksanakan di rumah melalui pembelajaran jarak jauh atau daring. Sekolah SMP Al Qolam Muhammadiyah Gemolong menerapkan keputusan dari menteri pendidikan untuk 
melaksanakan pembelajaran secara daring sampai kondisi lebih memungkinkan. Meskipun pembelajaran dilaksanakan secara daring, aktivitas dan materi pembelajaran tetap mengacu pada kurikulum yang telah ditetapkan. Kurikulum yang saat ini diterapkan di SMP Al Qolam Muhammadiyah Gemolong adalah kurikulum 2013. Kurikulum 2013 adalah kurikulum yang mencakup kompetensi sikap, pengetahuan, dan keterampilan yang dimiliki peserta didik (Indriasih, 2015:128).

Berdasarkan hasil wawancara dengan guru mata pelajaran bahasa Indonesia kelas VIII di SMP Al Qolam Muhammadiyah Gemolong, sekolah tersebut merupakan salah satu SMP yang melaksanakan pembelajaran daring. Perencanaan pembelajaran daring mulai menyiapkan media pembelajaran yang bisa dipahami oleh siswa. Contoh dalam menyiapkan siswa untuk mulai mengunduh aplikasi yang digunakan untuk pembelajaran daring. Pelatihan bagaimana cara menggunakan aplikasi, kemudian baru masuk dalam pembelajaran daring. Siswa mudah bosan dalam pembelajaran seperti ini. Upaya dalam menghadapi pembelajaran daring yaitu 1) memfasilitasi paket data untuk siswa, agar mudah dalam melaksanakan pembelajaran daring; 2) membuat media yang menarik; 3) membuat quis sebagai pengganti ulangan harian, terutama pada pembelajaran bahasa Indonesia yang bertujuan mengembangkan berbagai keterampilan pada pembelajaran daring. Alasan memilih kelas VIII, karena guru sangat memanfaatkan teknologi dalam pembelajaran.

Berdasarkan uraian di atas, peneliti bertujuan untuk integrasi mendeskripsikan technological pedagogical content knowledge (TPACK) guru bahasa Indonesia SMP Al Qolam Muhammadiyah Gemolong dalam merancang RPP daring mata pelajaran bahasa Indonesia.

\section{B. KAJIAN TEORI}

TPACK merupakan pengetahuan baru yang dikuasai guru untuk mengintegrasikan teknologi dalam pembelajaran (Mishra \& Koehler dalam Permatasari, 2020:271). Menurut Mishra dan Koehler dalam Sutrisno (2012:101) TPACK adalah kerangka kerja bagi guru dalam memadukan teknologi dalam pembelajaran. Sedangkan Baran dan Thompson dalam Pulungtana (2020:148) TPACK sebagai alat meningkatkan kemampuan guru dalam menguasai teknologi dalam proses pembelajaran. 
p-ISSN: 2301-5926 | e-ISSN: 2579 793X

TPACK kerangka pengetahuan yaitu teknologi, pedagogik, dan isi (Mishra dan Koehler dalam Hilmi, 2020:54). Menurut Mishra \& Koehler dalam Prasetyo (2019:1415) TPACK kerangka pengetahuan teknologi, pedagogik, dan konten. Sedangkan Rahmadi (dalam Nervita, 2020:204) TPACK adalah persimpangan dari teknologi, pedagogik, dan konten mempengaruhi dalam pembelajaran.

\section{METODE PENELITIAN}

Penelitian ini merupakan penelitian dengan jenis deskriptif kualitatif. Jenis penelitian kualitatif merupakan penelitian yang dilakukan untuk memahami fenomena yang alami oleh subjek penelitian berkenaan dengan motivasi, Tindakan, perilaku, persepsi, dan lain-lain (Moleong, 2017:6). Metode penelitian kualitatif ini diterapkan untuk mendeskripsikan integrasi TPACK dalam RPP daring dan hasil wawancara dengan guru mata pelajaran Bahasa Indonesia. Data dalam penelitian ini adalah komponenkomponen dalam RPP daring mata pelajaran bahasa Indonesia di SMP Al Qolam Muhammadiyah Gemolong tahun ajaran 2020/2021. Adapun sumber data dalam penelitian ini adalah RPP daring mata pelajaran bahasa Indonesia di SMP AL Qolam Muhammadiyah Gemolong pada tahun pelajaran 2020/2021.

Pengumpulan data dalam penelitian ini dilakukan dengan teknik dokumentasi dan wawancara. Teknik dokumentasi dilakukan dengan mengumpulkan RPP daring mata pelajaran bahasa Indonesia di SMP Al Qolam Muhammadiyah Gemolong tahun ajaran 2020/2021. Teknik wawancara dilakukan dengan cara mewawancarai guru mata pelajaran bahasa Indonesia di SMP AL Qolam Muhammadiyah Gemolong. Proses wawancara kepada guru bahasa Indonesia untuk memperoleh informasi yang lebih mendalam penyusunan RPP daring.

Penelitian ini menggunakan teknik triangulasi sumber mengarahkan peneliti menggunakan sumber data seperti informasi yang diberikan oleh narasumber, untuk memperoleh data peneliti mengamati secara mendalam setiap informasi yang diberikan informan mengenai integrasi TPACK dan kendala yang dialami guru dalam menyusun RPP daring. Selanjutnya, tahap analisis data kualitatif menurut (Bogdam \& Biklen dalam Moleong, 2017:248) dilakukan dengan cara reduksi data, penyajian data, dan verifikasi. 


\section{HASIL DAN PEMBAHASAN}

Analisis integrasi TPACK dikelompokan menjadi 4 bagian, yaitu integrasi technological knowledge, integrasi pedagogical knowledge, integrasi content knowledge, dan integrasi technologigal pedagogical content knowledge guru bahasa Indonesia kelas VIII SMP Al Qolam Muhammadiyah Gemolong dalam menyusun RPP daring tahun ajaran 2020/2021.

RPP daring guru bahasa Indonesia kelas VIII semester gasal tahun ajaran 2020/2021 yang dianalisis sejumlah 2 RPP dengan rincian sebagai berikut.

a. RPP 1 berisi KD 3.1 dan 4.1 tentang teks berita.

b. RPP 2 berisi KD 3.5 dan 4.5 tentang teks eksposisi.

Selanjutnya masing-masing aspek dianalisis dengan sub aspek sesuai uraian pada tabel berikut.

Tabel 1 Daftar Aspek dan Sub Aspek TPACK

\begin{tabular}{|c|c|c|}
\hline Pengetahuan & Aspek & Sub Aspek \\
\hline $\begin{array}{l}\text { Technological } \\
\text { Knowledge } \\
\text { (TK) }\end{array}$ & $\begin{array}{l}\text { Pengetahuan } \\
\text { Teknologi }\end{array}$ & $\begin{array}{l}\text { Penggunaan Teknologi } \\
\text { dalam langkah-langkah } \\
\text { pembelajaran dan media } \\
\text { pembelajaran }\end{array}$ \\
\hline $\begin{array}{l}\text { Pedagogical } \\
\text { Knowledge } \\
(\mathrm{PK})\end{array}$ & $\begin{array}{l}\text { Pengetahuan } \\
\text { Mengajar }\end{array}$ & $\begin{array}{l}\text { Penerapan pendekan, } \\
\text { model, dan metode dalam } \\
\text { langkah-langkah } \\
\text { pembelajaran }\end{array}$ \\
\hline $\begin{array}{l}\text { Content } \\
\text { Knowledge } \\
\text { (CK) }\end{array}$ & $\begin{array}{l}\text { Pengetahuan } \\
\text { Materi }\end{array}$ & $\begin{array}{ll}\text { Keluasan Materi dan } \\
\text { Kedalaman Materi }\end{array}$ \\
\hline $\begin{array}{l}\text { Technologigal } \\
\text { Pedagogical } \\
\text { Content } \\
\text { Knowledge } \\
\text { (TPACK) }\end{array}$ & $\begin{array}{l}\text { Pengetahuan } \\
\text { Teknologi, } \\
\text { Pedagogik, dan } \\
\text { Konten }\end{array}$ & \begin{tabular}{llr}
\multicolumn{2}{l}{ Kesesuain } & kegiatan \\
dengan metode, media, & yang \\
dan materi & digunakan.
\end{tabular} \\
\hline
\end{tabular}

Berdasarkan tabel 1 diketahui untuk dapat menganalisis TPACK tahapan yang perlu dianalisis meliputi technological knowledge, pedagogical knowledge, content knowledge, dan technologigal pedagogical content knowledge. Selanjutnya integrasi TPACK melalui analisi technological knowledge, pedagogical knowledge, content knowledge, dan technologigal pedagogical content knowledge dipaparkan sebagai berikut. 
a. Integrasi Technological Knowledge dalam RPP daring Kelas VIII SMP Al Qolam Muhammadiyah Gemolong

Pada kegiatan menyusun RPP daring selama pandemi ini guru harus menguasai penggunaan teknologi untuk pembelajaran daring. Pada integrasi technological knowledge guru bahasa Indonesia kelas VIII menggunakan teknologi dalam pembelajaran dilihat dari komponen RPP daring yang terdapat di bagian langkah-langkah pembelajaran dan media pembelajaran. Di antaranya seperti mengoperasikan aplikasi Google Classroom, Email, Whatsapp Group, Google From, Microsoft Teams, dan Zoom dalam pembelajaran. Awal pandemi guru menggunakan aplikasi google classroom dan whatsapp group dalam pembelajaran daring. Mulai tahun ajaran baru guru menggunakan aplikasi microsoft teams dan zoom dalam pembelajaran daring. Guru memaksimalkan penggunaan aplikasi whatsapp group dalam pembelajaran daring. Hal tersebut sesuai dengan penelitian Busyra (2020) whatsapp digunakan sebagai komunikasi dalam pembelajaran. Penelitian Bulan (2020) google formulir sebagai proses pembelajaran daring. Integrasi TK pada masing-masing RPP di dalam langkahlangkah pembelajaran tergambar dalam uraian berikut.

Tabel 2 Integrasi TK dalam RPP daring mata pelajaran bahasa Indonesia

\begin{tabular}{|c|c|c|}
\hline $\begin{array}{l}\text { RPP } \\
\text { ke- }\end{array}$ & $\begin{array}{l}\text { Media } \\
\text { Pembelajaran } \\
\text { dan Sumber } \\
\text { Belajar } \\
\end{array}$ & Bentuk Integrasi \\
\hline \multirow{4}{*}{1} & $\begin{array}{l}\text { a. Google } \\
\text { Form }\end{array}$ & a. Guru melakukan presensi online. \\
\hline & $\begin{array}{l}\text { b. Google } \\
\text { Classroom }\end{array}$ & $\begin{array}{l}\text { b. Peserta didik membaca teks berita tentang covid- } \\
19 \text { pada yang disampaikan guru melalui aplikasi } \\
\text { google classroom. }\end{array}$ \\
\hline & $\begin{array}{l}\text { c. Whattsapp } \\
\text { Group }\end{array}$ & $\begin{array}{l}\text { c. Guru menggunakan aplikasi whatsapp group } \\
\text { dalam pembelajaran. }\end{array}$ \\
\hline & $\begin{array}{l}\text { d. Microsoft } \\
\text { Teams }\end{array}$ & $\begin{array}{l}\text { d. Peserta didik membaca contoh-contoh teks berita } \\
\text { dari internet yang dibagikan guru melalui } \\
\text { microsoft teams. }\end{array}$ \\
\hline \multirow{2}{*}{2} & $\begin{array}{l}\text { a. Google } \\
\text { Form }\end{array}$ & a. Guru melakukan presensi online. \\
\hline & $\begin{array}{l}\text { b. Power } \\
\text { Point }\end{array}$ & $\begin{array}{l}\text { b. Berdasarkan teks eksposisi pada panduan guru } \\
\text { yang ditayangkan guru dengan media power point, }\end{array}$ \\
\hline
\end{tabular}




\begin{tabular}{l|l|l}
\hline & \multicolumn{2}{|c}{$\begin{array}{l}\text { peserta didik menganalisis ciri-ciri dan unsur-unsur } \\
\text { teks eksposisi. }\end{array}$} \\
\cline { 2 - 3 } & $\begin{array}{l}\text { c. Aplikasi } \\
\text { Zoom }\end{array}$ & $\begin{array}{l}\text { c. Peserta didik menyajikan hasil belajarnya meliputi } \\
\text { unsur-unsur, ciri-ciri, pengertian, serta pola } \\
\text { pengembangan teks eksplanasi melalui aplikasi } \\
\text { zoom meeting. }\end{array}$ \\
\cline { 2 - 3 } & d. Youtube & $\begin{array}{l}\text { d. Peserta didik mengamati tayangan manfaat buah } \\
\text { pir bagi kesehatan melalui tautan video youtube } \\
\text { yang telah disiapkan oleh guru } \\
\text { https://www.youtobe.com/watch? }=\mathrm{SW7g500iQeo}\end{array}$ \\
\hline
\end{tabular}

b. Integrasi Pedagogical Knowledge dalam RPP daring Kelas VIII SMP Al Qolam Muhammadiyah Gemolong

Bagian integrasi pedagogical knowledge dalam RPP daring mencakup aspek pengetahuan strategi pembelajaran. Dilihat dari komponen RPP daring kelas VIII SMP Al Qolam Muhammadiyah Gemolong di bagian tujuan pembelajaran. Pada aspek pengetahuan strategi pembelajaran guru mencantumkan model discovery learning dan model saintifik. Hal tersebut sesuai dengan penelitian Bayuaji (2017) pembelajaran student facilitator and explaining dengan pendekatan saintifik diterapkan guru dalam pembelajaran. Penelitian Putrayasa (2014) model pembelajaran discovery learning meningkatkan belajar peserta didik dengan memberikan pengalaman.

Tabel 3 Integrasi PK dalam RPP daring mata pelajaran bahasa Indonesia

\begin{tabular}{|c|c|c|c|}
\hline $\begin{array}{l}\text { RPP } \\
\text { ke- }\end{array}$ & $\begin{array}{l}\text { Model yang } \\
\text { Diterapkan }\end{array}$ & Tahapan Model Pembelajaran & Bentuk Integrasi \\
\hline \multirow{3}{*}{1} & \multirow{3}{*}{$\begin{array}{l}\text { Discovery } \\
\text { Learning }\end{array}$} & Tahap Pemberian Rangsangan & $\begin{array}{l}\text { Peserta didik } \\
\text { membaca contoh- } \\
\text { contoh teks berita } \\
\text { dari internet. }\end{array}$ \\
\hline & & Tahap Pernyataan/Identifikasi & $\begin{array}{ll}\text { Peserta didik } & \text { melakukan curah } \\
\text { pendapat untuk } \\
\text { menggali } \\
\text { pengetahuan } \\
\text { berkaitan dengan } \\
\text { teks yang dibaca. }\end{array}$ \\
\hline & & Tahap Pengumpulan Data & $\begin{array}{lr}\text { Peserta didik } \\
\text { mendata informasi } \\
\text { dengan membaca } \\
\text { sumber lain tentang }\end{array}$ \\
\hline
\end{tabular}


p-ISSN: 2301-5926 | e-ISSN: 2579 793X

\begin{tabular}{|c|c|c|c|}
\hline & & & $\begin{array}{l}\text { ciri dan unsur teks } \\
\text { berita. }\end{array}$ \\
\hline & & Tahap Pengolahan Data & $\begin{array}{l}\text { Peserta didik } \\
\text { menentukan } \\
\text { pokok-pokok isi } \\
\text { berita yang dibaca } \\
\text { dengan } \\
\text { memperhatikan } \\
\text { contoh. }\end{array}$ \\
\hline & & Tahap Pembuktian & $\begin{array}{l}\text { Peserta didik } \\
\text { menyusun } \\
\text { ringkasan isi berita } \\
\text { berdasarkan } \\
\text { pokok-pokok berita } \\
\text { yang ditulis. }\end{array}$ \\
\hline & & $\begin{array}{l}\text { Tahap Menarik } \\
\text { Simpulan/Generalisasi }\end{array}$ & $\begin{array}{l}\text { Peserta didik } \\
\text { menyimpulkan isi } \\
\text { berita berdasarkan } \\
\text { ringkasan berita } \\
\text { yang telah disusun. }\end{array}$ \\
\hline & & Mengamati & $\begin{array}{l}\text { Peserta didik } \\
\text { menyaksikan } \\
\text { tayangan manfaat } \\
\text { buah pir bagi } \\
\text { kesehatan pada } \\
\text { alamat web yang } \\
\text { telah disiapkan } \\
\text { guru. }\end{array}$ \\
\hline 2 & Saintifik & Menanya & $\begin{array}{l}\text { Peserta didik dan } \\
\text { guru melakukan } \\
\text { bertanya jawab } \\
\text { untuk menggali } \\
\text { pengetahuan } \\
\text { berkaitan dengan } \\
\text { tayangan yang } \\
\text { telah disaksikan } \\
\text { melalui aplikasi } \\
\text { zoom. }\end{array}$ \\
\hline & & $\begin{array}{l}\text { Mengumpulkan } \\
\text { Informasi/Mencoba }\end{array}$ & $\begin{array}{lr}\text { Berdasarkan } & \text { teks } \\
\text { eksposisi } & \text { dan } \\
\text { panduan guru yang } \\
\text { ditayangkan } & \text { guru } \\
\text { dengan } & \text { media } \\
\text { power } & \text { point, } \\
\text { peserta didik } & \text { menganalisis ciri- } \\
\text { ciri dan unsur- }\end{array}$ \\
\hline
\end{tabular}




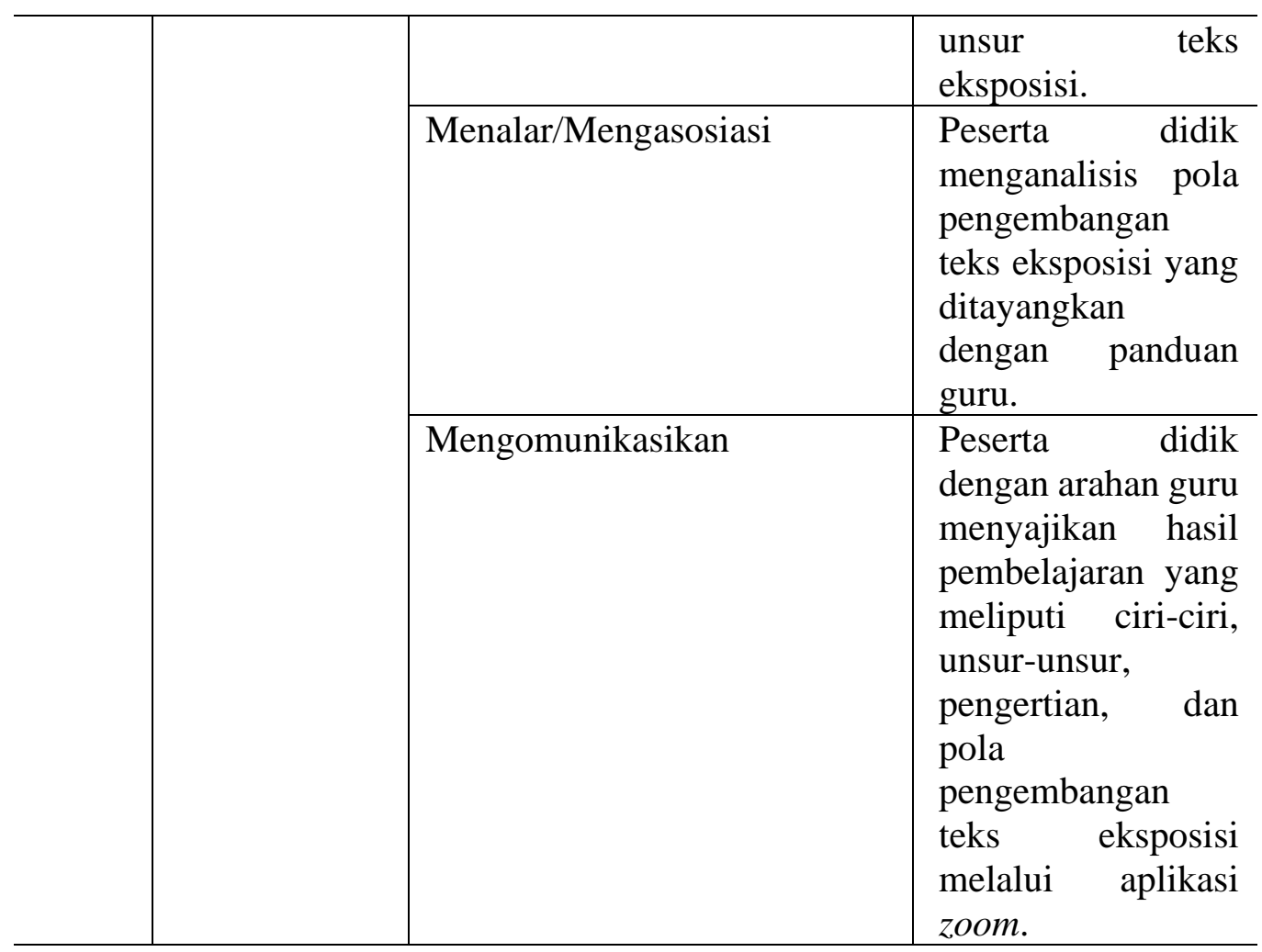

c. Integrasi Content Knowledge dalam RPP Daring VIII SMP Al Qolam Muhammadiyah Gemolong

Integrasi content knowledge meliputi keluasan materi dan kedalaman materi. Keluasan materi dan kedalaman materi dilihat dari komponen RPP daring kelas VIII SMP Al Qolam Muhammadiyah Gemolong dibagian lampiran. Pada RPP pertama sampai RPP kedelapan guru tidak mencantumkan materi di dalam RPP daring. Namun, pada contoh soal yang terdapat di dalam RPP daring guru dapat menjabarkan soal. Guru menyusun RPP daring praktis perencanaannya, sehingga guru menggunakan materi ajar berupa pedoman pada buku teks dan modul belajar. Hal tersebut sesuai dengan penelitian Kuka (2017) guru mencantumkan materi ajar dalam RPP. penelitian Maolana (2018) RPP mengandung komponen-komponen secara lengkap dan baik.

Tabel 4 Integrasi CK dalam RPP daring mata pelajaran bahasa Indonesia

\begin{tabular}{c|c|c|cr}
\hline $\begin{array}{c}\text { RPP } \\
\text { ke- }\end{array}$ & \multicolumn{1}{|c|}{ KD } & \multicolumn{1}{c}{ Materi } & \multicolumn{2}{|c}{ Bentuk Integrasi } \\
\hline 1 & $\begin{array}{l}3.1 \quad \text { Mengidentifikasi } \\
\text { unsur-unsur teks berita } \\
\text { (mengembangkan dan }\end{array}$ & $\begin{array}{l}\text { a. Definisi Teks } \\
\text { Berita, Ciri- } \\
\text { ciri Teks }\end{array}$ & $\begin{array}{l}\text { a. Materi teks berita } \\
\text { ditayangkan guru } \\
\text { dengan media }\end{array}$ \\
\hline
\end{tabular}


p-ISSN: 2301-5926 | e-ISSN: 2579 793X

\begin{tabular}{|c|c|c|c|}
\hline & \multirow{2}{*}{$\begin{array}{l}\text { memotivasi) yang } \\
\text { didengar dan dibaca. } \\
\text { 4.1 Menyimpulkan isi } \\
\text { berita } \\
\text { (mengembangkan dan } \\
\text { memotivasi yang } \\
\text { dibaca dan didengar. }\end{array}$} & \multirow{2}{*}{$\begin{array}{l}\text { Berita, dan } \\
\text { Jenis-jenis } \\
\text { Teks Berita } \\
\text { b. Unsur-unsur } \\
\text { dalam Teks } \\
\text { Berita } \\
\text { c. Simpulan, } \\
\text { Tanggapan, } \\
\text { dan } \\
\text { Penyampaian } \\
\text { Isi Teks Berita } \\
\text { d. Struktur dan } \\
\text { Kebahasaan } \\
\text { Teks Berita } \\
\text { e. Penyusunan } \\
\text { Teks Berita }\end{array}$} & $\begin{array}{l}\text { power point. } \\
\text { Seperti definisi, } \\
\text { ciri, jenis teks } \\
\text { berita, dan lain } \\
\text { sebagainya. }\end{array}$ \\
\hline & & & $\begin{array}{ll}\text { b. Materi yang ada } \\
\text { didalam modul } \\
\text { belajar } & \text { seperti } \\
\text { menentukan } & \text { unsur- } \\
\text { unsur } & \text { berita, } \\
\text { menyimpulkan teks } & \\
\text { berita, } & \text { dan } \\
\text { sebagainya. }\end{array}$ \\
\hline \multirow[b]{2}{*}{2} & \multirow{2}{*}{$\begin{array}{l}3.5 \text { Mengidentifikasi } \\
\text { informasi teks } \\
\text { eksposisi berupa } \\
\text { artikel ilmiah populer } \\
\text { dari koran/majalah } \\
\text { yang didengar dan } \\
\text { dibaca. } \\
4.5 \text { Menyimpulkan isi } \\
\text { teks eksposisi (artikel } \\
\text { ilmiah populer dari } \\
\text { koran dan majalah) } \\
\text { yang diperdengarkan } \\
\text { dan dibaca. }\end{array}$} & \multirow{2}{*}{$\begin{array}{l}\text { a. Pengertian dan } \\
\text { Ciri khusus } \\
\text { Teks Eksposisi } \\
\text { b. Menentukan } \\
\text { Informasi } \\
\text { dalam Teks } \\
\text { Eksposisi } \\
\text { c. Menyimpulkan } \\
\text { Isi Teks } \\
\text { Eksposisi } \\
\text { d. Menganalisis } \\
\text { Struktur dan } \\
\text { Kaidah } \\
\text { Kebahasaan } \\
\text { dalam Teks } \\
\text { Eksposisi } \\
\text { e. Menulis Teks } \\
\text { Eksposisi }\end{array}$} & $\begin{array}{l}\text { a. Guru } \\
\text { menyampaikan } \\
\text { materi tentang teks } \\
\text { eksposisi dengan } \\
\text { menggunakan } \\
\text { power point. } \\
\text { Seperti pengertian, } \\
\text { ciri teks eksposisi, } \\
\text { dan sebagainya. }\end{array}$ \\
\hline & & & $\begin{array}{l}\text { b. Dalam modul } \\
\text { belajar terdapat } \\
\text { materi mengenali } \\
\text { unsur-unsur teks } \\
\text { eksposisi, } \\
\text { menyimpulkan isi } \\
\text { teks berita, dan } \\
\text { sebagainya. }\end{array}$ \\
\hline
\end{tabular}

d. Integrasi Technologigal Pendagogical Content Knowledge dalam RPP Daring Kelas VIII SMP Al Qolam Muhammadiyah Gemolong

Pada RPP daring integrasi TPACK yaitu pengintegrasian teknologi, keterampilan, dan materi pembelajaran. Dilihat dari komponen-komponen RPP daring Kelas VIII SMP Al Qolam Muhammadiyah Gemolong dibagian langkahlangkah pembelajaran terdapat kegiatan pendahuluan, kegiatan inti, dan kegiatan penutup. Pada RPP daring kegiatan pendahuluan, guru memberi motivasi dan 
presensi. Pada kegiatan inti, guru memberi alamat web mengenai materi. Guru melakukan interaksi dengan siswa mengenai materi yang telah disampaikan. Pada kegiatan penutup, guru menyimpulkan materi. Hal tersebut sesuai dengan penelitian Muspawi (2014) pemahaman guru tentang rencana pelaksanaan pembelajaran bervariasi. Penelitian Fuziah (2013) guru memberi semangat motivasi belajar kepada peserta didik.

Tabel 5 Integrasi TPACK dalam RPP daring mata pelajaran bahasa Indonesia

\begin{tabular}{|c|c|c|c|c|c|}
\hline $\begin{array}{l}\mathrm{RPP} \\
\mathrm{Ke}-\end{array}$ & KD & Materi & Media & $\begin{array}{c}\text { Penerapan } \\
\text { Model } \\
\text { Pembelajaran } \\
\end{array}$ & Bentuk Integrasi \\
\hline \multirow{6}{*}{1} & \multirow{6}{*}{$\begin{array}{l}3.1 \\
\text { Mengidentifikasi } \\
\text { unsur-unsur teks } \\
\text { berita } \\
\text { (mengembangkan } \\
\text { dan memotivasi) } \\
\text { yang didengar dan } \\
\text { dibaca. } \\
\text { 4.1 Menyimpulkan } \\
\text { isi berita } \\
\text { (mengembangkan } \\
\text { dan memotivasi } \\
\text { yang dibaca dan } \\
\text { didengar. }\end{array}$} & \multirow{6}{*}{$\begin{array}{l}\text { a. Definisi Teks } \\
\text { Berita, Ciri- } \\
\text { ciri Teks } \\
\text { Berita, dan } \\
\text { Jenis-jenis } \\
\text { Teks Berita } \\
\text { b. Unsur-unsur } \\
\text { dalam Teks } \\
\text { Berita } \\
\text { c. Simpulan, } \\
\text { Tanggapan, } \\
\text { dan } \\
\text { Penyampaian } \\
\text { Isi Teks Berita } \\
\text { d. Struktur dan } \\
\text { Kebahasaan } \\
\text { Teks Berita } \\
\text { e. Penyusunan } \\
\text { Teks Berita }\end{array}$} & \multirow{6}{*}{$\begin{array}{l}\text { Aplikasi } \\
\text { Google } \\
\text { Form,WA } \\
\text { Grup dan } \\
\text { Microsoft } \\
\text { Teams }\end{array}$} & $\begin{array}{l}\text { Tahap } \\
\text { Pemberian } \\
\text { Rangsangan }\end{array}$ & $\begin{array}{lr}\text { Peserta } & \text { didik } \\
\text { membaca } & \text { contoh- } \\
\text { contoh teks berita } \\
\text { dari internet. }\end{array}$ \\
\hline & & & & $\begin{array}{l}\text { Tahap } \\
\text { Pernyataan/Id } \\
\text { entifikasi }\end{array}$ & $\begin{array}{lr}\text { Peserta } & \text { didik } \\
\text { melakukan } & \text { curah } \\
\text { pendapat } & \text { untuk } \\
\text { menggali } & \\
\text { pengetahuan } & \\
\text { berkaitan dengan } & \\
\text { teks yang dibaca. }\end{array}$ \\
\hline & & & & $\begin{array}{l}\text { Tahap } \\
\text { Pengumpulan } \\
\text { Data }\end{array}$ & $\begin{array}{l}\text { Peserta } \\
\text { mendata informasi } \\
\text { dengan membaca } \\
\text { sumber lain tentang } \\
\text { ciri dan unsur teks } \\
\text { berita. }\end{array}$ \\
\hline & & & & $\begin{array}{l}\text { Tahap } \\
\text { Pengolahan } \\
\text { Data }\end{array}$ & $\begin{array}{l}\text { Peserta didik } \\
\text { menentukan pokok- } \\
\text { pokok isi berita yang } \\
\text { dibaca dengan } \\
\text { memperhatikan } \\
\text { contoh. }\end{array}$ \\
\hline & & & & $\begin{array}{l}\text { Tahap } \\
\text { Pembuktian }\end{array}$ & $\begin{array}{l}\text { Peserta didik } \\
\text { menyusun ringkasan } \\
\text { isi berita berdasarkan } \\
\text { pokok-pokok berita } \\
\text { yang ditulis }\end{array}$ \\
\hline & & & & $\begin{array}{l}\text { Tahap } \\
\text { Menarik }\end{array}$ & $\begin{array}{lr}\text { Peserta } & \text { didik } \\
\text { menyimpulkan } & \text { isi }\end{array}$ \\
\hline
\end{tabular}


p-ISSN: 2301-5926 | e-ISSN: 2579 793X

\begin{tabular}{|c|c|c|c|c|c|}
\hline & & & & $\begin{array}{l}\text { Simpulan/Ge } \\
\text { neralisasi }\end{array}$ & $\begin{array}{l}\text { berita berdasarkan } \\
\text { ringkasan berita yang } \\
\text { telah disusun. }\end{array}$ \\
\hline \multirow{5}{*}{2} & \multirow{5}{*}{$\begin{array}{l}3.5 \\
\text { Mengidentifikasi } \\
\text { informasi teks } \\
\text { eksposisi berupa } \\
\text { artikel ilmiah } \\
\text { populer dari } \\
\text { koran/majalah } \\
\text { yang didengar dan } \\
\text { dibaca. } \\
4.5 \text { Menyimpulkan } \\
\text { isi teks eksposisi } \\
\text { (artikel ilmiah } \\
\text { populer dari koran } \\
\text { dan majalah) yang } \\
\text { diperdengarkan } \\
\text { dan dibaca. }\end{array}$} & \multirow{5}{*}{$\begin{array}{l}\text { a. Pengertian dan } \\
\text { Ciri khusus } \\
\text { Teks Eksposisi } \\
\text { b. Menentukan } \\
\text { Informasi } \\
\text { dalam Teks } \\
\text { Eksposisi } \\
\text { c. Menyimpulka } \\
\text { n Isi Teks } \\
\text { Eksposisi } \\
\text { d. Menganalisis } \\
\text { Struktur dan } \\
\text { Kaidah } \\
\text { Kebahasaan } \\
\text { dalam Teks } \\
\text { Eksposisi } \\
\text { e. Menulis Teks } \\
\text { Eksposisi }\end{array}$} & \multirow{5}{*}{$\begin{array}{l}\text { Aplikasi } \\
\text { Zoom, } \\
\text { Youtube } \\
\text { dan } \\
\text { Google } \\
\text { Form }\end{array}$} & Mengamati & $\begin{array}{lr}\text { Peserta } & \text { didik } \\
\text { menyaksikan } & \\
\text { tayangan manfaat } \\
\text { buah pir bagi } \\
\text { kesehatan } \\
\text { alamat web yang } \\
\text { telah disiapkan guru. }\end{array}$ \\
\hline & & & & Menanya & $\begin{array}{l}\text { Peserta didik dan } \\
\text { guru melakukan } \\
\text { curah pendapat untuk } \\
\text { menggali } \\
\text { pengetahuan } \\
\text { berkaitan dengan } \\
\text { tayangan yang telah } \\
\text { disaksikan melalui } \\
\text { aplikasi zoom. }\end{array}$ \\
\hline & & & & $\begin{array}{l}\text { Mengumpulk } \\
\text { an } \\
\text { Informasi/Me } \\
\text { ncoba }\end{array}$ & $\begin{array}{lr}\text { Berdasarkan teks } \\
\text { eksposisi } \\
\text { panduan guru yang } \\
\text { ditayangkan guru } \\
\text { dengan media power } \\
\text { point, peserta didik } \\
\text { menganalisis ciri-ciri } \\
\text { dan unsur-unsur teks } \\
\text { eksposisi. }\end{array}$ \\
\hline & & & & $\begin{array}{l}\text { Menalar/Men } \\
\text { gasosiasi }\end{array}$ & $\begin{array}{lr}\text { Peserta } & \text { didik } \\
\text { menganalisis } & \text { pola } \\
\text { pengembangan } & \text { teks } \\
\text { eksposisi } & \text { yang } \\
\text { ditayangkan dengan } & \\
\text { panduan guru. } & \end{array}$ \\
\hline & & & & $\begin{array}{l}\text { Mengomunik } \\
\text { asikan }\end{array}$ & $\begin{array}{l}\text { Dengan panduan } \\
\text { guru, peserta didik } \\
\text { menyampaikan hasil } \\
\text { belajarnya (ciri-ciri, } \\
\text { unsur-unsur, } \\
\text { pengertian, dan pola } \\
\text { pengembangan teks } \\
\text { eksposisi) melalui } \\
\text { aplikasi zoom. }\end{array}$ \\
\hline
\end{tabular}

E. KESIMPULAN 
Berdasarkan hasil penelitian integrasi TPACK dikelompokan menjadi 4 bagian dalam RPP daring di SMP Al Qolam Muhammadiyah Gemolong. Pertama, integrasi technological knowledge (TK) yang dapat dilihat dalam penggunaan media pembelajaran dan sumber belajar. Kedua, integrasi pedagogical knowledge (PK) yang dapat dilihat dari pemilihan model pembelajaran dan integrasinya dalam langkah-langkah pembelajaran. Ketiga, integrasi content knowledge (CK) yang dilihat dari kesesuain materi dengan kompetensi yang akan dicapai. Keempat, integrasi technologigal pendagogical content knowledge (TPACK) dilihat dalam pembelajaran kesesuain antara kompetensi dasar dengan materi, media, sumber belajar, model pembelajaran, dan integrasinya dalam langkah-langkah pembelajaran.

\section{F. SARAN}

Berdasarkan hasil penelitian di atas, memiliki beberapa saran sebagai berikut.

1) Penelitian ini sebagai rujukan bagi guru dan calon guru dalam merancang perencanaan pembelajaran daring mengacu TPACK.

2) Penelitian ini dapat menjadi acuan bagi peneliti selanjutnya dalam melakukan penelitian mengenai kompetensi guru khususnya kompetensi TPACK.

\section{DAFTAR PUSTAKA}

Agustina, Putri. 2015. Pengembangan PCK (Pedagogical Content Knowledge) Mahasiswa Calon Guru Biologi FKIP Universitas Muhammadiyah Surakarta Melalui Simulasi Pembelajaran. Jurnal Penelitian dan Pembelajaran IPA, 1(1):115.

Ariani, Dessy Noor. 2015. Hubungan antara Technological Pedagogical Content Knowledge dengan Technology Integration Self Efficacy Guru Matematika di Sekolah Dasar. Jurnal Madrasah Ibtidaiyah, 1(1):79-91.

Bayuaji, dkk. 2017. Pengaruh Model Pembelajaran Kooperatif Tipe Student Facilitator and Explaining (SFAE) dengan Pendekatan Saintifik Terhadap Hasil Pembelajaran Fisika. Jurnal Pijar MIPA, 12(1):15-18.

Bulan dan Husniyatus. 2020. Pembelajaran Online Berbasis Media Google Formulir dalam Tanggap Work From Home Masa Pandemi Covid-19 di Madrasah

Busyra dan Lutfiah. 2020. Kinerja Mengajar dengan Sistem Work From Home (WFH) pada Guru di SMK Purnawarman Purwakarta. Jurnal Pendidikan Islam, 3(1):118.

Fauziah, dkk. 2013. Pembelajaran Saintifik Elektronika Dasar Berorientasi Pembelajaran Berbasis Masalah. INVOTEC, 9(2):165-178. 
p-ISSN: 2301-5926 | e-ISSN: 2579 793X

Fitriani, dkk. 2017. Kompetensi Profesional Guru dalam pengelolaan Pembelajaran di MTs Muhammadiyah Banda Aceh. Jurnal Magister Administrasi Pendidikan Pascasarjana Universitas Syiah Kuala, 5(2):88-95.

Hilmi, dkk. 2020. Tahap Pengetahuan Guru Bahasa Arab dalam Melaksanakan Kelas Terbalik. MJSSH Online, 4(3):50-67.

Kuka, Udin. 2017. Upaya Meningkatkan Kompetensi Guru dalam Menyusun Rencana Pelaksanaan Pembelajaran Melalui Bimbingan Berkelanjutan di SMP Negeri 10 Kota Ternate. Jurnal Pendidikan, 15(1):643-649.

Maolana, Asep Dimyadi. (2018). "Peningkatan Kompetensi Guru dalam Menyusun Rencana Pelaksanaan Pembelajaran Melalui In House Training". Jurnal Pendidikan Tambusai, 2(5):953-969.

Muspawi, Mohamad. (2014). "Profesionalitas Guru dalam Menyusun Rencana Pelaksanaan Pembelajaran (RPP) Pada Sekolah Dasar Negeri No. 76/IX Desa Mendalo Darat Kec. Jaluko Kab. Muaro Jambi”. Jurnal Penelitian Universitas Jambi Seri Humaniora, 17(1):57-62.

Nervita, dkk. 2020. Analisis Kompetensi TPACK Guru Melalui Media Pembelajaran Biologi SMA. Jurnal Pendidikan Sains Indonesia, 8(2):203-217.

Permatasari, Diah Ayu. 2020. Pentingnya Technological Pedagogical Content Knowledge (TPACK) Pada Matematika Di Era Revolusi Industri 4.0. Jurnal Pendidikan, 2(1):272-278.

Prasetyo, dkk. 2019. Pengaruh Literasi TIK Terhadap Technological Pedagogical Content Knowledge (TPACK) Guru. Jurnal Pendidikan, 6(1):13-20.

Pulungtana 2020. Evaluasi Kinerja Mengajar Guru IPS dalam Mengimplementasikan TPACK. Jurnal Ilmu Sosial dan Humaniora, 9(1):146-155.

Putrayasa, dkk. 2014. Pengaruh Model Pembelajaran Discovery Learning dan Minat Belajar Terhadap Hasil Belajar IPA Siswa. Jurnal Mimbar PGSD Universitas Pendidikan Ganesha, 2(1):1-11.

Rosyid, Abdul. 2016. Technological Pedagogical Content Knowledge: Sebuah Kerangka Pengetahuan Bagi Guru Indonesia Di Era Mea. : Prosiding Seminar Nasional Inovasi Pendidikan, hlm.450-460.

Setiawati, Wiwik. 2017. Meningkatkan Kemampuan Guru Kimia SMA dalam Merencanakan Pembelajaran Kimia Berbasis Model Pembelajaran Melalui Pelatihan Kurikulum 2013 Jenjang SMA Tahun 2016. Jurnal Ilmu Pendidikan LPMP Kalimantan Timur, 11(1):133-146. 